Ана Голубовић

Универзитет у Београду

Филолошки факултет
016: [811.16:061.6

https://doi.org/10.18485/melissa.2017.16.1.ch8

\title{
ЗНАЧАЈ ПРВИХ МЕЪУНАРОДНИХ СКУПОВА СЛАВИСТА ЗА РАЗВОЈ БИБЛИОГРАФИЈЕ
}

\section{Сажетак}

I Међународни конгрес слависта одржан у Прагу 1929. године поставио је тему израде текуће библиографије из области славистике као једну од главних тема. Одлуке донесене на том, као и подршка коју је идеја славистичке библиографије добила на наредном конгресу у Варшави 1934. сведоче о месту библиографских истраживања у славистичким оквирима и о посвећености слависта, како лингвиста тако и историчара и теоретичара књижевности.

Посебан осврт на дотадашња достигнућа и смернице за даљи развој славистичка библиографија је добила на страницама штампаног и припремљеног материјала за III Међународни конрес слависта који је требало да буде одржан у Београду 1939. године. Прво, мање формално међународно окупљање слависта након Другог свтеског рата у Београду 1955. године донело је потврду тих становишта.

Библиогрсфкој делатности у српској славистици допринело је залагање на међународном нивоу Александра Белића, Павла Поповића, Степана Куљбакина, Радована Лалића.

Кључне речи: Међународни конгрес слависта, славистичка библиографија, текућа библиографија, лингвистичка библиографија, књижевно-историјска библиографија.

Идејаопокретањусвеобухватнесловенскетекућебиблиографије једна је од најамбициознијих идеја у оквиру сарадње славистичких центара с почетка XX века. На прва два Међународна конгреса слависта, у Прагу 1929. и Варшави 1934. године, дефинисани су циљеви и формулисани задаци научних институција у спровођењу библиографских задатака. Водећа три научна часописа која су као своје сталне рубрике имала већ одељке за лингвистичку библиографију били су Јужнословенски филолог, Sborník Filologický и Rocznik Slawistyczny. 
Први конгрес словенских филолога одржан је 1929. године у Прагу од 6. до 13. октобра. Александар Белић је тај догађај представио као сусрет где су се по први пут састали научници из разних делова Европе и имали прилике да упореде своје послове (БЕлић 1928-1929: 160). Програм Конгреса је био подељен у три секције: историјско-књижевна, лингвистичка, педагошко-методолошка. Према оцени А. Белића, учесник је имао времена да учествује и присуствује дискусијама само једне од њих, што није наишло на његово одобравање. Десети број часописа Прилози за књижевност, језик, историју и фолклор за 1930. годину у засебној рубрици, у првој свесци, донео је извештаје са истог конгреса. Павле Поповић и Степан Куљбакин су писали о организацији, распореду излагања, секцијама и екскурзији. Индикативно је како се у неким запажањима погледи уредника Прилога за књижевност, језик, историју и фолклор и Јужнословенског филолога на одређене појединости разликују. Док се Александар Белић (БЕлић 1928-1929) жалио на систем паралелних секција, Павле Поповић (Поповић - КуљБАкин 1930) то наводи као организациону предност.

Првог радног дана, на Општој седници Прве и Друге секције повела се расправа о „заједничкој, исцрпној библиографији” (Белић 1928-1929: 166). Сваки од говорника истицао је важност библиографије а изнет је и предлог о оснивању центра за библиографију у Прагу при Словенском институту. Александар Белић је предложио да лингвистички часописи доносе библиографију једнообразно „по једноме плану [...] (са кратким садржајем и описом дела) свега онога из области филологије и лингвистике што излази у границама [...]" (Белић 1928-1929: 166). Резултат те иницијативе била је прва резолуција Конгреса која гласи:

„I Конгрес словенских филолога у Прагу прима обавезу претставника словенских филолошких часописа да ће сваке године на време доносити библиографију дела и чланака научне вредности који се тичу словенских језика, а који су излазили у дотичној држави.

Библиографија ће доносити по утврђеном плану садржину и карактеристику дела и чланака.

Комисија за утврђивање плана: Белић, Милетич, Њич и Хујер" (Белић 1928-1929: 166). 
Тај документ је један од најзначајнијих за развој и значај библиографије која и данас постоји у уужнословенском филологу. Одлука о изради библиографске рубрике која ће бити стална у часопису објашњена је речима: „Имајући на уму корист коју испитивачима могу пружити исцрпно вођени и критичким примедбама пропраћени библиографски прегледи[...] ми ћемо засада давати на крају сваке године библиографију само онога што је из славистике изашло у току од године дана на нашем језику и што је другде за то време о нашем језику изашло." (СтолАновић - БЕлић 1913: 4)

Додатну вредност резолуцији даје то што је један од њених потписника био уредник Јужнословенског филолога. Оваквом одлуком целокупна међународна славистичка научна јавност дала је пуну подршку развоју библиографије радова из области славистике. Библиографски рад постао је саставни део научно-истраживачког процеса и задатак многих часописа. Овом резолуцијом прецизно су дефинисани оквири у којима ће се свака од тих библиографија кретати:

- национална - обрађује се грађа у оквиру једне државе;

- текућа - часописи који су добили задатак њене израде објављивани су најчешће као годишњаци; на тај начин обезбеђен је континуитет излажења;

- селективна - стриктно се наводи да се узимају у обзир само материјали од научне вредности;

- анотирана - предложено је и да се поред основног библиографског описа пруже информације и оцене о садржају дела.

Конгресу је присуствовао несразмерно мали број учесника из Русије (9) у односу на број учесника из Југославије (20) или Пољске (чак 40) , на пример. Период пре Другог светског рата не карактерише тешња научна сарадња између других славистичких центара и новоосноване совјетске државе. Недостатак комуникације с руским научницима био је евидентан јер је донета одлука да се рад на библиографској грађи из Русије повери Руском научном институту у Београду и Словенском институту у Прагу. Одлучено је такође да ће библиографију везану за лужичкосрпски израђивати чешки часопис Slavia, а накнадно је требало да се донесе одлука о томе ко ће се бавити материјалом из несловенских земаља. 
Библиографска рубрика Јужнословенског фрилолога је на тај начин постала део свесловенског пројекта где је, заједно са другим водећим славистичким часописима, постао део једног великог, за развој наше научне текуће библиографије вредног система.

Насловљен као годишњак, часопис Rocznik Slawistyczny је од свог оснивања у Кракову 1908. до почетка Другог светског рата излазио као једнотомник, доносећи радове с темама везаним за словенску филологију. Прва два броја, из 1908. и 1909. године, састојала су се из два одељка. Први део су чинили критички подробни прикази оних научних радова из области словенске филологије на које је уређивачки одбор сматрао да треба да укаже. Други део чинила је библиографија научних монографија и радова у зборницима из области опште лингвистике и славистике. Почев од трећег броја часопис Rocznik Slawistyczny има сталне три рубрике: расправе, приказе и библиографију. Прва свеска броја шеснаест, после Другог светског рата, објављена је 1948. године, у којој су, као и раније, публиковани научни радови и прикази књига. Друга свеска садржала је библиографију. Она је објављена две године касније, 1950. Таква пракса се одржала наредних 40 година. После 1991. и броја 47 библиографија се одвојила од часописа и прерасла у низ обимних прегледа под називом Bibliografia Językoznawstwa Slawistycznego.

у Чешкој је почетком XX века Академија наука, њено филолошко одељење, 1910. године покренула часопис Sborník Filologický који је текућом библиографијом пратио научне радове чешких филолога (Хујер 1922-1923). Часопис Slavia, покренут 1922. године, није као део свог програма имао објављивање библиографије лингвистичких радова, што се наводи у уводном тексту (Úvodem 1922-1923: 1). Уређивачки одбор је тада сматрао да не постоји потреба израде такве библиографије везане за територију Чехословачке пошто је већ постојала, и имала велики углед, општа словенска библиографија пољског часописа Rocznik Slawistyczny. У кратком временском периоду после Другог светског рата, од 1951. до 1955. године, Slavia је објавила библиографије словенске филологије за четири године (1950-1953). Главни аргументи били су све већи временски раскорак између текуће календарске године и оне за који је грађа презенто- 
вана у славистичкој библиографији пољског часописа и непотпуне библиографије других лингвистичких гласила (француског Revue des Études Slaves, на пример).

Одлуке донесене на Првом потврђене су на Другом конгресу словенских филолога у Варшави 1934. године. Број 14, свеска 1-2 (1934) Прилога за књижевност, језик, историју и фолклор садржи обиман извештај са изразито позитивним освртом на теме и одлуке Конгреса. Павле Поповић је на крају најавио Трећи међународни славистички конгрес, планиран да се одржи у Београду 1939. године и предложио да буде посвећен Доситеју Обрадовићу, поводом двестогодишњице његовог рођења. ${ }^{1}$

Трећи међународни конгрес слависта, планиран за септембар 1939. године у Беогарду, није одржан. ${ }^{2}$ У комплетно припремљеним свескама забележена је иста безрезервна подршка развоју текуће славистичке библиографије.

„Организовање словенске филолошке и лингвистичке библиографије Извршни одбор повешће преговоре да се организује Централни биро на једном месту, са сталним кореспондентима у осталим словенским центрима.

Треба осигурати излажење библиографије најдаље за пола године од протекле године.

Финансијска средства пружиле би Академије, учена друштва и Владе" (Трећи конгрес слависта: организација 1939: 30).

„а) Иако је учињен покушај да се изврши такво организовање још на Првом конгресу слависта, ипак данашње функционисање те организације има више недостатака (у неједнако време излазе библиографије, неједнаке по материјалу који се у њима износи и сл.)

б) Потребно је да једна установа словенска узме на себе тај посао, а остала средишта словенска да је помажу слањем исцрпне библиографске грађе која се тиче њихове земље.

1 Први конгрес био је посвећен Јосифу Добровском а Други Адаму Мицкјевичу. Трећи међународни конгрес слависта био је планиран да се одржи од 18. до 25. септембра 1939. године. Његово одржавање онемогућио је почетак Другог светског рата 1. септембра 1939. године. 
в) Трошак би сносили респективни народи или респективне установе. Редакција би била у рукама уског круга људи који се налазе при установи која би руководила тим послом.

г) Одредио би се одбор који би израдио правила о функционисању те организације и који би остао као стална врховна управа његова"

(БЕлић 1939: 89).

Истомишљенике је Александар Белић имао многобројне, према рефератима и исказима који су штампани: Бохуслав Хаврањек, Кирил Тарановски и др.

Одлуке првих славистичких конгреса дају слику о томе којим путем је требало да се креће словенска библиографија и националне библиографије које би је чиниле. Степен организације који је могао бити постигнут био би велики. Један од научника који се највише залагао и имао визију како се то може остварити био је оснивач и уредник Јужнословенског фрилолога. Може се само претпоставити какво би место југословенска славистичка библиографија на тај начин стекла.

После Другог светског рата, у сасвим измењеним околностима које су владале у словенским државама, општа словенска библиографија никада није организована на начин за који су се научници раније залагали. Библиографије сличне садржине и оријентације, било као рубрике у научном часопису или монографске публикације, покренуте су након Другог светског рата у Совјетском савезу, Бугарској, Словенији и Македонији.

Број 21, свеска 3-4 Прилога за књижевност, језик, историју и фолклор за 1955. годину доноси у рубрици „Хроника и библиографија” извештај Радована Лалића о првом послератном међународном састајању слависта које је организовано у Београду. Како трећи, потпуно припремљен конгрес 1939. године у Београду није одржан, стога је било симболично што је Београд био иницијатор, додуше неформалног, окупљања након рата од 15. до 21. септембра 1955. године. У извештају је наведено како организатори нису били нескромни да сусрет научника назову конгресом (ЛАлић 1955). Циљ је био да се остваре први контакти након рата на међународном нивоу, зарад обнављања веза и даље сарадње. Није позван велики број учесника, 
али су били заступљени сви водећи славистички научни центри из осамнаест земаља.

Одлуке које су донесене на седницама одржаним у оквиру сусрета дају велики значај том састанку. Најважнија од њих је свакако она о оснивању Међународног славистичког комитета, планираног да броји дванаест делегата, са дванаест заменика из истог броја земаља. ${ }^{3}$ Договорено је да следећи, трећи по реду, конгрес буде одржан у Москви 1958. године.

Питање израде и објављивања јединствене славистике библиографије била је, такође, једна од тема. „Не мањи значај има одлука о издавању славистичке библиографије. Данас није потребно доказивати да успешан рад на појединим гранама славистике није могућ без систематске библиографије, како лингвистичке тако и књижевноисториске" (ЛАлић 1955: 395).

Чланови новооснованог комитета били су сагласни при одлуци да су се стекли услови за објављивање јединствене славистичке библиографије из области лингвистике у пољском часопису Rocznik Slawistyczny. Национални научни центри су добили задатак да библиографски материјал сакупњен током једне календарске године шаљу уредништву часописа („Извештај о Међународном славистичком састанку..." 2016: 14). Пописана грађа је трабало да пружи податке о актуелним научним радовима и публикацијама, представљеним путем основних библиографских података и кратке садржине. Уколико је неки од записа садржао и оцену приказане јединице, морао је бити потписан. Прецизирано је, такође, да трошкови израде и слања леже на националним академијама и универзитетима.

Организацију рада на библиографији из области књижевне историје и теорије је теже било одредити. До тог тренутка ни један научни центар није имао сличну праску израде и објављивања

3 Изабрани су: В. Георгијев (П. Динеков) из Бугарске; Б. Хавранек (Ј. Долански) из Чехословачке; А. Мазон (А. Вајан) из Француске; Ђ. Мавер (Е. Ло Гато) из Италије; А. Белић (А. Барац) из Југославије; М. Фасмер (Р. Јагодич) из Немачке и Аустрије; Т. Лер-Сплавињски (В. Дорошевски) из Пољске; Е. Петровић (И. Књежа) из Румуније и Мађарске; Р. Јакобсон (В. Ледњицки) ис САД; А. Стендер-Петерсен (Г. Гунарсон) из скандинавских земаља; В. Виноградов (В. Борковски) из СССР; Е. Хил (В. К. Метјуз) из Велике Британије. 
библиографија. Библиографска делатност није била стални нити саставни део рада неке институције или часописа. Стога је планирање тог сегмента славистичке библиографије било нешто другачије и комплексније. Било је речи о објављивању више свезака, у неколико научних центара, ${ }^{4}$ где би посао био распоређен према областима и периодима, што се библиографске грађе тиче.

Организација библиографског рада је највиши степен досегла у оквиру пољског часописа Rocznik Slawistyczny из Кракова, из чега је касније произишла међународна лингвистичка библиографија из области славистике Bibliografia językoznawstwa slawistycznego. Библиографија пољског часописа је прво прерасла у међународну славистичку библиографију а затим у базу података доступну путем Интернета. ${ }^{5}$ У југословенској научној средини се издвојила библиографија коју негује Јужнословенски филолог, с редовном рубриком. „Библиографија” Јужнословенског филолога је од самог почетка замишљена као текућа кумулативна. Посебном је и данас чине континуитет у њеном излажењу и ширина обрађиваног материјала.

\section{Литература:}

БЕлић, Александар. „Први Конгрес оловенских(sic!) филолога у Прагу 1929 г. од 6-13 октобра." Јужнословенски филолог бр. VIII (1928-1929): стр. 160-178.

БЕлић, Александар. „Предлог о организовању филолошке и лингвистичке библиографије." Трећи Конгрес слависта : одговори на питања. Београд: САН, 1939: стр. 89.

Београдски међународни славистички састанак : 15-21. IX 1955. : посебан описак. Београд: Организациони одбор, 1957.

ВРАНЕш, Александра. Библиографија. Београд: Филолошки факултет, 2013.

4 Сугестија са завршне седнице била је и да славистичку књижевноисторијску библиографију из несловенских земаља израђује Универзитет у Лајдену.

5 http://www.isybislaw.ispan.waw.pl 
ВРАНЕШ, Александра. Основи теорије и историје библиографије. Бањалука: Народна и универзитетска библиотека Републике Српске; Београд: Филолошки факултет, 2010.

ВРАНЕШ, Александра. „Почеци Библиографског института у Српском семинару Филозофског факултета у Београду." Анали Филолошког факултета 21 (2009): стр. 141-159.

ГолуБовић, Ана. Библиографија у часопису Јужнословенски филолог. Београд: Институт за српски језик САНУ, 2013.

ГолуБовић, Ана. „Библиографије у периодичним публикацијама Филолошког факултета Универзитета у Београду." Србија између истока и запада: наука, образовање, култура, уметност : тематски зборник у 4 књиге. Књ. 2, Библиотеке и библиографија у савременом културолошком диверзитету (ур.) Александра Вранеш, Љиљана Марковић. Београд: Филолошки факултет, 2014: стр. 323-344.

ГолуБовић, Ана. „Стогодишњица часописа Rocznik Slawistyczny.” Зборник Mamuце српске за славистику бр. 75 (2009): стр. 245-252.

„Други конгрес словенских филолога: 22-30 септембар 1934.” Прилози за књижевност, језик, историју и фолклор бр. ХІV, св. 1-2 (1934): стр. 275-283.

„Извештај о Међународном славистичком састанку одржаном у Београду од 15. до 21. септембра 1955." Александар Белић : српски лингвиста века. Београд: Филолошки факултет, 2016: стр. 1-24. [додатак]

ЛАлић, Радован. „Међународни славистички састанак у Београду.” Прилози за књижевност, језик, историју и фолклор бр. XXI, св. 3-4 (1955): стр. 394-398.

ПипЕР, Предраг. „О библиографској делатности Катедре за славистику и Славистичког друштва Србије." Славистика бр. IX (2005): стр. 425-427.

Поповић, Павле. КуљБАКин, Степан. „Први конгрес словенских филолога: 5-13 октобра 1929 у Прагу." Прилози за књижевност, језик, историју и фолклор бр. Х, св. 1 (1930): стр. 155-161.

„Сарадња наших научника у страним научним публикацијама." Прилози за књижевност, језик, историју и фолклор бр. XXI, св. 1-2 (1955): стр. 182-183.

СтолАновић, Љубомир. БЕлић, Александар. „Поводом покретања Јужнословенског филолога." Јужнословенски фрилолог бр. I (1913): стр. 2-4.

ТАРАНОВски, Кирил. „Међународни славистички конгрес у Београду." Јужнословенски филолог бр. ХXI, св. 1/4 (1955-1956): стр. 278-279.

Трећи конгрес слависта. Београд: САН, 1939.

ХУЈЕР, Олдржих. „Чешка филологија и лингвистика 1907-1921 год." Јужнословенски филолог бр. III (1922-1923): стр. 112-130.

„Úvodem." Slavia br. 1, sv. 1 (1922-1923): str. 1-2. 


\section{Ana Golubović}

\section{THE SIGNIFICANCE OF THE FIRST SEVERAL INTERNATIONAL SLAVIC GATHERINGS ON THE DEVELOPMENT OF SLAVIC BIBLIOGRAPHY}

\section{Summary}

The First International Slavic Congress held in Prague in 1929 made the topic of the current bibliography in the field of Slavic Studies as one of the important topics. Conclusions made then, as well as the support that the idea of Slavic bibliography received at the next congress in Warsaw in 1934, testify of significance of bibliographic research in Slavic frameworks and the commitment of Slavic scholars, both linguists and literary historians.

Special reference of the achievements and guidelines for further development of Slavic Bibliography is shown in printed material prepared for the Third International Slavic Congress which was to be held in Belgrade in 1939. First, less formal international gathering of Slavic scholars after the World War II in Belgrade in 1955 brought confirmation of these views.

Special commitment of Aleksandar Belić, Pavle Popović, Stepan Kuljbakin, Radovan Lalić is evident in the development of the Serbian Slavic bibliography.

Key words: International Slavic Congress, Slavic bibliography, current bibliography, linguistic bibliography, literary and historical bibliography. 